\title{
Histological, Histomorphometrical and Histochemical Studies on the Large Intestine of Uttara Fowl
}

\author{
K. Pandit ${ }^{*}$, B.S. Dhote ${ }^{1}$, D. Mahanta ${ }^{1}$, S. Sathapathy ${ }^{2}$, \\ S. Tamilselvan ${ }^{1}$, M. Mrigesh ${ }^{1}$ and S. Mishra ${ }^{3}$ \\ ${ }^{1}$ Department of Veterinary Anatomy, C.V.A.Sc., GBPUAT, Pantnagar - 263 145, \\ Uttarakhand, India \\ ${ }^{2}$ Department of Veterinary Anatomy and Histology, C.V.Sc. and A.H., OUAT, \\ Bhubaneswar - 751003, Odisha, India \\ ${ }^{3}$ Division of Veterinary Pathology, ICAR-Indian Veterinary Research Institute, \\ Izzatnagar - 243 122, Bareilly, U.P, India \\ *Corresponding author
}

\section{A B S T R A C T}

\begin{tabular}{|c|}
\hline Keywords \\
\hline $\begin{array}{l}\text { Histology, } \\
\text { Histomorphometry, } \\
\text { Histochemistry, Large } \\
\text { intestine, Uttara fowl }\end{array}$ \\
\hline Article Info \\
\hline $\begin{array}{l}\text { Accepted: } \\
12 \text { February } 2018 \\
\text { Available Online: } \\
10 \text { March } 2018\end{array}$ \\
\hline
\end{tabular}

\begin{abstract}
The present study was conducted on 24 Uttara fowl. The histological, histomorphometrical and histochemical features with their age related changes in large intestine were studied. The surface epithelium in both caeca and colorectum was lined by simple columnar epithelium with interspersed goblet cells. Finger like villous projections were seen in the tunica mucosa. PAS- Alcian blue reaction was showed by all the segments of caecum as well as colorectum. Presence of Elastic fibres around the blood vessels, between muscle layers of tunica muscularis and lamina propria was found in caecum and colorectum of 112 days old bird. Masson's trichrome stain showed presence of collagen fibres in tunica serosa, between muscle fibres, in core of villi and around intestinal glands. Gomori's stain showed presence of reticular fibers, which was maximum in 112 days old bird. Argentaffin cells were present in epitheliums of intestinal gland and villi mostly in contact with basement membrane.
\end{abstract}

\section{Introduction}

Uttara fowl is a well adopted bird found in the taral region of Uttarakhand (Kaur et al., 2010). Their germplasm is unexplored and possess various potential genes responsible for survival in rough conditions of hilly terrain of Uttarakhand. This breed has evolved through natural selection in indigenous agro-ecological conditions and is well adapted to the local environment. It has low cholesterol content in their blood which makes it suitable for heart patients and obese people. It has high glucose level in its blood due to more energy requirement at high altitude, more activity and more flying tendency than commercial birds (Kaur, 2007). Fundamentals for the production performance in a poultry flock are their genetic merit, management and health. The study of avian gastrointestinal tract anatomy is still in its infancy and needs to be further explored as it plays a vital role in feed 
utilization which ultimately affects the overall productivity of the bird. There are many nutritional reports on the avian intestinal system but very little is known about the detailed anatomy of large intestine (Bayer et al., 1981; Turk, 1982). Different fields of veterinary and animal sciences are dependent on the anatomy and histology of body organs (Argenzio, 1980). The large intestine due to its lympahatic tissue aggregates in the colon and caeca has a major immunological role (Ushakumary S. et al., 2002). Caecal functioning is still only partly understood (McNab, 1973; Braun and Duke 1989). However, research of many decades has revealed its role in energy balance and osmoregulation which involves absorption of material from the caecum. Caeca may also serve as the site for several different functions, especially digestion of small food particles, absorption of nutrients, production of immunoglobulins, utilization and absorption of water and metabolism of uric acid into amino acids. Caecotomy has shown to increase the water intake and increased excretion of water in faeces (Son et al., 2000)

Reports are available on the histological structure and age related changes in certain organs of digestive system of guinea fowl, Japanese quail, and Kadaknath fowl (Sivagnanam et al., 2004; Venkatasan et al., 2005 and Vaish et al., 2006). Samte (2008) carried out Gross morphometric, light and electron microscopic studies on the large intestine of Kadaknath fowl. Persual of literature revealed limited information pertaining to the large intestine of Uttara fowl. The histological structure of digestive tract differs from species to species among birds depending upon their nature of feed (Marshall, 1960). Keeping in view the above consideration, the present study was conducted to study detailed histology, histomorphometry and histochemistry of large intestine of Uttara fowl.

\section{Materials and Methods}

\section{Experimental birds}

To carry out study on structural organization of the large intestine of Uttara fowl, a total of twenty-four birds were purchased from Instructional Poultry Farm, G.B Pant University of Agriculture and Technology, Pantnagar. All the birds were vaccinated against Newcastle disease and Infectious Bursal disease with primary (for both) and booster (for Newcastle disease) doses.

\section{Experimental design}

Based on age, the birds were divided into four group viz. day old, 7, 28 and 112 days old birds with six birds in each age group. On each observation day, six birds were utilized for gross morphometrical features of the large intestine, from these birds tissue samples were preserved for histological, histomorphometrical and histochemical studies.

\section{Histological studies}

After the organs were carefully dissected out, the gross measurements were taken and then cross sections of around 4-5 $\mathrm{mm}$ were cut using BP blade and the samples were then immediately washed using normal saline solution gently to remove the fecal matter. After washing the tissues were immediately fixed in $10 \%$ neutral buffered formalin. After 48 hours of fixation the tissues were washed overnight under running tap water in tissue cassettes.

To remove water from the tissues, ascending grades of alcohol (viz. 50\%, 70\%, 80\%, 90\% and three changes in 100\%) one hour each were used. Xylene-I and xylene-II, one hour each was used as a clearing agent, to clear alcohol from dehydrated tissues and makes the 
tissue translucent. After clearing with xylene, the tissues samples were immersed in paraffin bath I, II and III for 1 hour each at $62^{\circ} \mathrm{C}$ to ensure the penetration of paraffin into tissues as well as for the complete removal of clearing reagent. The tissues were oriented in melted paraffin, in order to make paraffin blocks. Soon after embedding, tissues in molds were kept overnight for cooling so that cassettes separate out from mold then the sections were trimmed until we start getting tissue sections. Blocks are then kept at -20 degree Celsius for hardening.

Sections were cut $4-5 \mu$ thickness in Leica microtome, Japan and stained with Hematoxylin and Eosin for general histoarchitecture, Masson's Trichome stain for collagen fibres, Weigerts-iron hematoxylin stain for elastic fibres gomori's reticular stain or reticular fibres Bancroft et al., (2013). Thereafter, the stained tissue sections were examined under Nikon Microscope and photomicrography was performed with eclipse $\mathrm{Ci}-\mathrm{L} / \mathrm{S}$ microscope.

\section{Histomorhmetrical parameters}

Micrometry of stained histological section was done after calibration with ocular to stage micrometer scale (Culling, 1969).

Parameters that taken for histomormphometrical studies were thickness of tunica mucosa, tunica submucosa, tunica muscularis, tunica serosa, epithelial cell height, nucleus size and villi height and width.

\section{Histochemical studies}

The histochemical studies were conducted by using PAS technique for carbohydrate (Mc Manus, 1946), Alcian blue for mucosubstances (Luna, 1972), Massonhamperl for argentaffin/chromaffin cells (Singh, 1964) and modified Geimsa method for chromaffin cell granules (Geimsa, 1902).

\section{Results and Discussion}

\section{Histological studies}

The large intestine (caecum and colorectum) of Uttara fowl comprised of four basic tunics or layers namely tunica mucosa, tunica submucosa, tunica muscularis and tunica serosa from within to outwards. Similar observations have also been reported by Nickel et al., (1977), Ushakumary et al., (1994), Sisson and Grossman (1953), Samte (2008) and Nasrin et al., (2012). The tunica mucosa layer possessed considerable complexity, being thrown into well-developed folds. It comprised of innermost lamina epithelialis resting on connective tissue layer, the lamina propria. The surface lining epithelium comprised of tall columnar cells and mucus secreting goblet cells (Fig. 1) as reported by Aitken (1958), Nickel et al., (1977) and Usha Kumary et al., (1994). The lamina propria consisted of loose connective tissue fibres infiltrated with large number of lymphocytes. The lymphoid tissues were found to be present in mucosa, submucosa and core of villi. These findings are in line with the findings of Majeed et al., (2009), Samte (2008) and Nasrin et al., (2012). The lamina muscularis mucosae in both caeca and colorectum consisted of thin layer of muscles which extended to the core of villus in the mucosal folds. The tunica submucosa was seen as a thin layer and was more or less absent in young ages. Small blood vessels were occasionally seen in the submucosa. Tunica muscularis was made up of two layers, inner circular and an outer longitudinal muscle layer. The outermost layer was tunica serosa, which was made up of loose connective tissue. Samte (2008) also reported in Kadaknath fowl that a thin layer of lamina muscularis mucosae is present having only a few bundles of muscle fibres which extends to the core of villi and mucosal folds in caecum as well as rectum. The height of the villi was more in proximal part compared to middle part of the caecum 
within the same group while the villi were short, blunt and very few in number in the distal part but large mucosal folds were present. The height and breadth of the villi increased in both proximal and middle parts as the age advanced. The increase in the height and width of villi at proximal part may be for better absorption of nutrients. These findings are in accordance with Samte (2008).

\section{Caecum}

The wall of caecum consisted of all the tunics i.e. tunica mucosa, tunica submucosa, tunica muscularis and tunica serosa and caecum was divided into proximal, middle and distal portions in all studied age groups as observed by Nasrin et al., (2012), Majeed et al., (2009), Samte (2008), Dellmann and Eurell (1998). The surface epithelial lining consisted of simple columnar cells and goblet cells. The lamina propria, submucosa and core of villi consisted of loose connective tissue fibres infiltrated with large number of lymphocytes. Similar observations were recorded by Majeed et al., (2009), Nasrin et al., (2012) in chicken and Samte (2008) in Kadaknath fowl. An aggregation of lymphocytes forming a nodular appearance was seen towards the base of crypts of Lieberkuhn in the lamina propria in 28 and 112 days old birds but they were not noted in other studied age groups. The lymphatic nodules enclosed by a capsule were observed only in case of distal portion of caecum in 28 and 112 days old birds only. Rest of the portions of caeca as well as colorectum showed lymphatic aggregations without presence of connective tissue capsule around them. Samte (2008) reported presence of lymphatic nodules only in 112 days old Kadaknath fowl and did not mention any finding regarding encapsulated lymphatic aggregations. The lamina muscularis in both right and left caeca consisted of thin layer of muscles which extended to the core of the villus and the mucosal folds as observed by
Samte (2008). The tunica muscularis consisted of an inner circular coat which was well developed but the outer longitudinal layer was thin and hardly appreciable in day old and 7 days old bird. The tunica serosa was also present and consisted of a loose connective tissue (Fig. 2).

The structure of proximal caeca resembles with the structure of jejunum giving indication of same functionality this finding is supported by Fenna and Boag (1974). The proximal part of caecum consisted of prominent villi. The villi being well developed both in length and breadth but the crypts of Liberkuhn were short and rounded. Nasrin et al., (2012), Majeed et al., (2009) and Samte (2008) also reported the presence of long villi in the proximal portion of caecum. Longer villi are interdigitating and opening is narrow, giving it a mesh like appearance hence it may function as a filter for large course particles entering into caeca. This finding is in accordance with Ferrer et al., (2008). Large numbers of goblet cells were present in epithelium but they did not outnumber the columnar cells in caecum. This finding is in accordance with Samte (2008), Dellmann and Eurell (1998). The lamina muscularis mucosa was poorly developed and consisted of only a few bundles of muscle fibres. The tunica submucosa was present as a thin layer. The proximal portion of caecum is composed of thicker tunica muscularis layer than middle and distal portions of caecum making its wall thicker. The tunica muscularis was composed of a thin, outer longitudinal layer and inner circular layer which was thicker than outer longitudinal layer. Calhoun (1954) in chicken reported that the tunica muscularis thickness and arrangement varies greatly within the entire length of the intestinal tracts. He reported that the proximal part of the caecum has tunica muscularis with thick inner circular and thin outer longitudinal muscle layer. The middle part of caecum had shorter but broader villi, mucosal folds were 
seen. The tunica submucosa was present as a thin layer below lamina muscularis mucosa but thickening of tunica submucosa was seen at the regions where plica was present. Plicae are well developed folds of the mucus membrane. Only a thin layer of the lamina muscularis mucosa was observed in the distal part of caecum which enters core of villi. Size of tunica muscularis externa increased in the middle portion of caecum. These are similar with Dellmann and Eurell (1998) and Samte (2008). In present study middle part of the caecum was showing distinct inner circular and outer longitudinal layer in chicks but definite arrangement of these layers was lost in older birds similar observations were recorded by Calhoun (1954).

The distal part of caecum was found to have large mucosal folds and the villi were short, straight and very few in numbers. This portion normally possessed the largest diameter of the whole organ, but the lamina muscularis mucosa, tunica submucosa and the tunica mucularis were very similar to preceding region. Samte (2008) reported that the distal portion of caecum contains mucosal folds and villi are very short. Dellman and Eurell (1998) reported that prominent villi were observed in the proximal portion, shorter and broader in middle portion and the distal portion was having short villi or devoid of villi. Nodular type of lymphoid aggregation was seen in the lamina propria of caecum of 28 days and 112 days old Uttara fowl but their presence was not noted in other age groups. Nickel et al., (1977) stated that the intestinal mucosa is rich in lymphoreticular tissue which is arranged diffusely or in follicles and even extends into the villi. They also reported that the lymphoid tissue is particularly abundant in the caeca. Majeed et al., (2009) reported the maximum numbers of lymphatic nodules were present in the proximal portion of caecum then middle and distal portions contains least number of lymphatic nodules while he did not find any significant difference in the length and width of lymphatic nodules in different portions of caecum. The lymphatic aggregation in the proximal portion of caeca forms a nodular structure, caecal tonsil which may act as immunological surveillance against foreign microorganisms entering caeca with urine as a result of reverse peristalsis same was reported by Getty (1975). Myentric plexus was observed in the outer longitudinal layer of tunica muscularis. Neuroendocrine cells with large round nuclei were observed in the crypts of lieberkuhn. Similar findings were reported by Samte (2008).

\section{Colorectum}

The wall of the colorectum at proximal, middle and distal portions consisted of tunica mucosa, tunica submucosa, tunica muscularis and tunica serosa in the entire studied group. The surface epithelial lining consisted of simple columnar cells with goblet cells. The columnar cells tend to be obscured by large number of distended goblet cells. Aitkin (1958) and Samte (2008) reported similar results in broiler, native fowl and Kadaknath fowl respectively. The lamina propria consisted of loose connective tissue fibres and was infiltrated with large number of lymphocytes. Nodular type of lymphoid aggregation was seen in the lamina propria of colon of 112 days old Uttara fowl but their presence was not noted in other age groups. The lamina muscularis of colorectum consisted of thin layer of muscles which extended to the core of villus in the mucosal folds.

The tunica submucosa was seen as a thin layer of connective tissue. Tunica muscularis was divided into tunica muscularis interna and externa. The tunica serosa was also present and consisted of a layer of loose connective tissue. 
The tunica muscularis consists of an inner circular layer which was well developed but the outer longitudinal layer was thin. Present results corresponds to the results of Sissons and Grossman (1953) who reported that the tunica muscularis is well developed in colon with the inner circular layer thicker than the outer longitudinal layer. The thickness of tunica muscularis was found to increase caudally in the present studies. Ushakumary et al., (1994) had reported similar observations in quail. The tunica mucosa of colorectum was thrown into villi. Sisson and Grossman (1953) and Nickel et al., (1977) in domestic fowl and Ushakumary et al., (1994) in quail reported the presence of villi in colon. In the proximal part of colon, villi were branched and digitated, few unbranched individual villus were also seen. The middle part of villi was digitated and branched similar to proximal part. In the distal part of colorectum there were large mucosal folds showing branching. The unbranched individual villi were also observed in between large mucosal folds in the distal region. However, among different age groups studied, the branched villi and mucosal folds were lesser in day old Uttara fowl. Ushakumary et al., (1994) reported that histological differences exist along the length of colon in initial and terminal portions in quail. They also observed that initial part of the colon presents branched and digitated villi while the terminal part of colon had a large mucosal fold with small villi. They also observed that the branched villi and the mucosal folds were lesser in the day old birds These observations corresponds to present studies contrary to these findings Sisson and Grossman (1953) reported that the villi in colon were short in chicken.

\section{Histomorphometry}

\section{Caecum}

The thickness of tunica mucosa, tunica submucosa, tunica muscularis of caecum were
105.95 $\pm 1.36 \quad$ (Table 1), 44.40 \pm 1.29 , $351.64 \pm 3.33$ (Table 2), 52.73 $\pm 0.93 \mu \mathrm{m}$ at proximal, $\quad 86.19 \pm 1.85, \quad 29.31 \pm 0.82$, $306.52 \pm 2.78,52.87 \pm 0.05 \mu \mathrm{m}$ at middle and $57.29 \pm 1.92, \quad 23.66 \pm 0.99, \quad 212.44 \pm 4.19$, $57.18 \pm 0.76 \mu \mathrm{m}$ at distal parts, respectively in a day old bird. Samte (2008) reported mean thickness of tunica mucosa, tunica submucosa and tunica muscularis of caecum as 98.22, 76.07, 311.25 $\mu \mathrm{m}$ at proximal part, 76.07, $49.8,286.35 \mu \mathrm{m}$ at the middle and 69.172, $47.02,127.27 \mu \mathrm{m}$ at the distal part in day old kadaknath fowl birds. In a 7 days old bird, mean thickness of tunica mucosa, tunica submucosa, tunica muscularis and tunica Serosa were $275.90 \pm 1.59,65.23 \pm 1.37$, $486.49 \pm 3.45,60.15 \pm 0.41 \mu \mathrm{m}$ at proximal, $160.39 \pm 3.12, \quad 41.89 \pm 0.59, \quad 456.24 \pm 3.78$, $62.13 \pm 0.18 \mu \mathrm{m}$ at middle and 135.9 \pm 1.76 , $30.54 \pm 2.86,300.52 \pm 3.06,65.17 \pm 0.19 \mu \mathrm{m}$ at distal parts, respectively. Hamedi et al., (2013) recorded mucosal, submucosal and muscular width in 10 day old Japanese Quail as 0.40, 0.09 and $0.06 \mathrm{~mm}$ in proximal portion 0.85 , 0.06 and $0.88 \mathrm{~mm}$ respectively for middle portion and $0.05,0.04$ and $0.6 \mathrm{~mm}$ at distal portion. Samte (2008) reported the mean thickness of Tunica Mucosa, Submucosa and muscularis as $250.37,85.77,450 \mu \mathrm{m}$ at the proximal, 222.72, 73.32, 301.57 $\mu \mathrm{m}$ at the middle and 208.87, 56.72, $201.97 \mu \mathrm{m}$ at the distal part in 7 days old Kadaknath fowl birds.

In 28 days old bird, mean thickness of tunica mucosa, tunica submucosa, tunica muscularis and tunica serosa was 320.82 \pm 3.04 , $114.50 \pm 1.71,884.55 \pm 3.23,65.93 \pm 0.72 \mu \mathrm{m}$ at proximal, $\quad 270.13 \pm 3.97, \quad 88.58 \pm 1.83$, $848.41 \pm 1.62,71.35 \pm 0.01 \mu \mathrm{m}$ at middle and $254.25 \pm 3.97, \quad 86.28 \pm 0.95, \quad 436.96 \pm 5.04$, $75.09 \pm 0.76 \mu \mathrm{m}$ at distal parts, respectively. Hamedi et al., (2013) recorded width of mucosa, submucosa and muscularis in 30 day old Japanese Quail as 0.45, 0.12 and $0.12 \mathrm{~mm}$ respectively at proximal end $0.89,0.06$ and $0.88 \mathrm{~mm}$ respectively at middle portion 1.38 , 0.06 and $1.27 \mathrm{~mm}$ respectively at distal 
portion. These Results are higher than present studies indicating faster growth in Japanese Quail than that of Uttara fowl. Samte (2008) recorded thickness of Tunica mucosa, Tunica submucosa, Tunica muscularis and found it to be $300.0,131.42,879.8 \mu \mathrm{m}$ at proximal, $257.3,127.32,557.47 \mu \mathrm{m}$ at the middle and $228.25,81.60,322.32 \mu \mathrm{m}$ at the distal part in 28 days old Kadaknath fowl.

In 112 days old bird, mean thickness of tunica mucosa, tunica submucosa, tunica muscularis and tunica serosa was 527.30 \pm 3.15 , $127.29 \pm 2.58,1466.60 \pm 6.29,82.59 \pm 0.70 \mu \mathrm{m}$ at proximal, $\quad 481.50 \pm 5.63, \quad 181.50 \pm 1.92$, $1271.16 \pm 4.05,87.75 \pm 0.18 \mu \mathrm{m}$ at middle and $410.10 \pm 2.57, \quad 106.37 \pm 1.16, \quad 682.53 \pm 6.81$, $91.61 \pm 0.18 \mu \mathrm{m}$ at distal parts, respectively. Samte (2008) recorded thickness of tunica mucosa, tunica submucosa and tunica muscularis and found it to be 496.62, 171.52, $1455 \mu \mathrm{m}$ at the proximal, 4565, 139.72, $1137.1 \mu \mathrm{m}$ at middle and 415.0, 130.02, $643.25 \mu \mathrm{m}$ at the distal part in 112-days respectively in Kadaknath fowl. Mean villus length and breadth of caecum in the present study was $252.73 \pm 4.6,185.21 \pm 2.19 \mu \mathrm{m}$ at proximal; $180.93 \pm 2.34,90.12 \pm 1.47 \mu \mathrm{m}$ at middle and $100.27 \pm 0.46$ and $65.21 \pm 3.49 \mu \mathrm{m}$ at distal parts for day-old; 344.15 \pm 3.8 , $129.83 \pm 1.55 \mu \mathrm{m}$ at proximal, $291.87 \pm 2.45$, $143.12 \pm 1.07 \mu \mathrm{m}$ at middle, $121.23 \pm 0.35$, $78.21 \pm 0.45 \mu \mathrm{m}$ at distal parts for 7 days; $650.91 \pm 2.72,171.87 \pm 1.37 \mu \mathrm{m}$ at proximal, $491.35 \pm 0.46,150.21 \pm 1.11 \mu \mathrm{m}$ at middle and $131.21 \pm 1.25,89.71 \pm 2.65 \mu \mathrm{m}$ at distal parts for 28 days and $890.21 \pm 1.34,281.67 \pm 1.29 \mu \mathrm{m}$ at proximal, $621.78 \pm 2.14,200.61 \pm 1.52 \mu \mathrm{m}$ at middle and $171.21 \pm 1.62,128.72 \pm 1.63 \mu \mathrm{m}$ at distal parts for 112 days old Uttara fowl birds. Samte (2008) recorded mean villus length and breadth of the caecum in Kadknath fowl as $262.63,105.98 \mu \mathrm{m}$ at proximal, $186.86,83.87$ $\mu \mathrm{m}$ at middle parts and $70.89,60.47 \mu \mathrm{m}$ at distal part for day-old; 334.74, $132.63 \mu \mathrm{m}$ at the proximal parts, $278.54,105.19 \mu \mathrm{m}$ at the middle parts and $110.34,70.56 \mu \mathrm{m}$ at distal parts for 7-days; 636.01, $163.78 \mu \mathrm{m}$ at proximal parts, $479.32,36.96 \mu \mathrm{m}$ at middle parts, $125.43,81.25 \mu \mathrm{m}$ at distal parts for 28 days and $875.31,275.64 \mu \mathrm{m}$ at the proximal parts, $623.19,175.19 \mu \mathrm{m}$ at middle parts and $150.56,120.76 \mu \mathrm{m}$ at distal parts for 112-days old birds.

\section{Colorectum}

The mean thickness of tunica mucosa, tunica submucosa, tunica muscularis and tunica serosa of colorectum were $148.75 \pm 1.64$, $43.72 \pm 1.12,322.57 \pm 2.03,52.65 \pm 0.09 \mu \mathrm{m}$ at proximal, $\quad 153.94 \pm 1.53, \quad 48.48 \pm 1.28$, $370.65 \pm 3.15,56.82 \pm 0.99 \mu \mathrm{m}$ at middle and $224.36 \pm 1.76, \quad 54.55 \pm 1.67, \quad 411.16 \pm 3.45$, $63.54 \pm 0.29 \mu \mathrm{m}$ at distal parts for day old; $219.88 \pm 3.27, \quad 49.16 \pm 1.37, \quad 535.88 \pm 3.45$, $61.23 \pm 0.41 \mu \mathrm{m}$ at proximal, $223.07 \pm 1.87$, $57.27 \pm 0.81,568.12 \pm 4.25,67.31 \pm 0.84 \mu \mathrm{m}$ at middle and $284.37 \pm 2.23, \quad 59.11 \pm 0.70$, $605.97 \pm 3.22,69.07 \pm 0.16 \mu \mathrm{m}$ at distal parts for 7 days old, $271.31 \pm 1.96, \quad 137.64 \pm 1.79$, $712.24 \pm 4.13,73.15 \pm 0.43 \mu \mathrm{m}$ at proximal, $293.19 \pm 1.87, \quad 74.57 \pm 0.93, \quad 740.56 \pm 4.11$, $72.16 \pm 0.95 \mu \mathrm{m}$ at middle and $343.11 \pm 0.41$, $90.74 \pm 0.91,888.10 \pm 2.65,75.21 \pm 0.47$ at distal part for 28 days old and $425.49 \pm 2.87$, $142.59 \pm 1.36,1377.19 \pm 2.51,82.36 \pm 0.19 \mu \mathrm{m}$ at proximal, $\quad 442.78 \pm 3.07, \quad 102.03 \pm 0.78$, $1460.41 \pm 4.35, \quad 87.54 \pm 0.59 \mu \mathrm{m}$ at middle, $479.87 \pm 2.83, \quad 161.54 \pm 1.37, \quad 1546.65 \pm 7.64$, $91.23 \pm 0.66 \mu \mathrm{m}$ at distal part for 112 days old Uttara fowl, respectively. In the present study the thickness of these tunics increased as the age advanced and these changes were quite evident from 28 days old Uttara fowl onwards. The thickness of tunica muscularis increased most significantly among all the tunics. The thickness of tunica mucosa and tunica submucosa did not change significantly in proximal and middle portions but at distal portion marked increase in the thickness was observed. 
Table.1 Mean thickness of tunica mucosa of various segments of large intestine $(\mu \mathrm{m})$

\begin{tabular}{|l|l|c|c|c|c|}
\hline \multirow{2}{*}{$\begin{array}{c}\text { Various } \\
\text { segments }\end{array}$} & & \multicolumn{4}{|c|}{ Age Group } \\
\cline { 2 - 7 } & & Day 1 & Day 7 & Day 28 & Day 112 \\
\hline \multirow{2}{*}{ Caecum } & Proximal portion & $105.95 \pm 1.36$ & $275.90 \pm 1.59$ & $320.82 \pm 3.04$ & $527.30 \pm 3.15$ \\
\cline { 2 - 7 } & Middle portion & $86.19 \pm 1.85$ & $160.39 \pm 3.12$ & $270.13 \pm 3.97$ & $481.50 \pm 5.63$ \\
\cline { 2 - 7 } & Distal portion & $57.29 \pm 1.92$ & $135.9 \pm 1.76$ & $254.25 \pm 3.97$ & $410.10 \pm 2.57$ \\
\hline \multirow{2}{*}{ Colorectum } & Proximal portion & $148.75 \pm 1.64$ & $219.88 \pm 3.27$ & $271.31 \pm 1.96$ & $425.49 \pm 2.87$ \\
\cline { 2 - 7 } & Middle portion & $153.94 \pm 1.53$ & $223.07 \pm 1.87$ & $293.19 \pm 1.87$ & $442.78 \pm 3.07$ \\
\cline { 2 - 7 } & Distal portion & $224.36 \pm 1.76$ & $284.37 \pm 2.23$ & $343.11 \pm 6.41$ & $479.87 \pm 2.83$ \\
\hline
\end{tabular}

Table.2 Mean thickness of tunica muscularis of various segments of large intestine $(\mu \mathrm{m})$

\begin{tabular}{|c|c|c|c|c|c|}
\hline \multirow{2}{*}{$\begin{array}{l}\text { Various } \\
\text { segments }\end{array}$} & & \multicolumn{4}{|c|}{ Age Group } \\
\hline & & Day 1 & Day 7 & Day 28 & Day 112 \\
\hline \multirow{3}{*}{ Caecum } & Proximal portion & $351.64 \pm 3.33$ & $486.49 \pm 3.45$ & $884.55 \pm 3.23$ & $1466.60 \pm 6.29$ \\
\hline & Middle portion & $306.52 \pm 2.78$ & $456.24 \pm 3.78$ & $848.41 \pm 1.62$ & $1271.16 \pm 4.05$ \\
\hline & Distal portion & $212.44 \pm 4.19$ & $300.52 \pm 3.06$ & $436.96 \pm 5.04$ & $682.53 \pm 6.81$ \\
\hline \multirow[t]{3}{*}{ Colorectum } & Proximalportion & $322.57 \pm 2.03$ & $535.88 \pm 3.64$ & $712.24 \pm 4.13$ & $1377.19 \pm 2.51$ \\
\hline & Middle portion & $370.65 \pm 3.15$ & $568.12 \pm 4.25$ & $740.56 \pm 4.11$ & $1460.41 \pm 4.35$ \\
\hline & Distal portion & $411.16 \pm 3.45$ & $605.97 \pm 3.22$ & $888.10 \pm 2.65$ & $1546.65 \pm 7.64$ \\
\hline
\end{tabular}

Fig.1 Photomicrograph showing goblet cells $(\mathrm{G})$, columnar cells (cc) in the villi of 112 days old bird. (H\&E X1000)

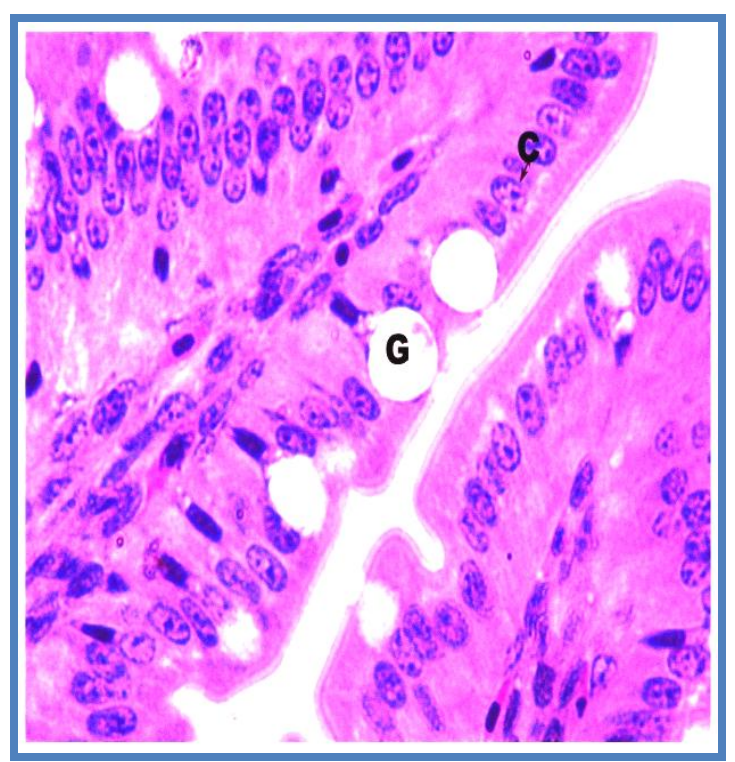


Fig.2 Photomicrograph showing long villi (V), crypts of lieberkuhn (CL), intestinal glands (IG), tunica muscularis (TM) and tunica serosa (TS) in proximal caecum of day old bird. (H\&E X100)

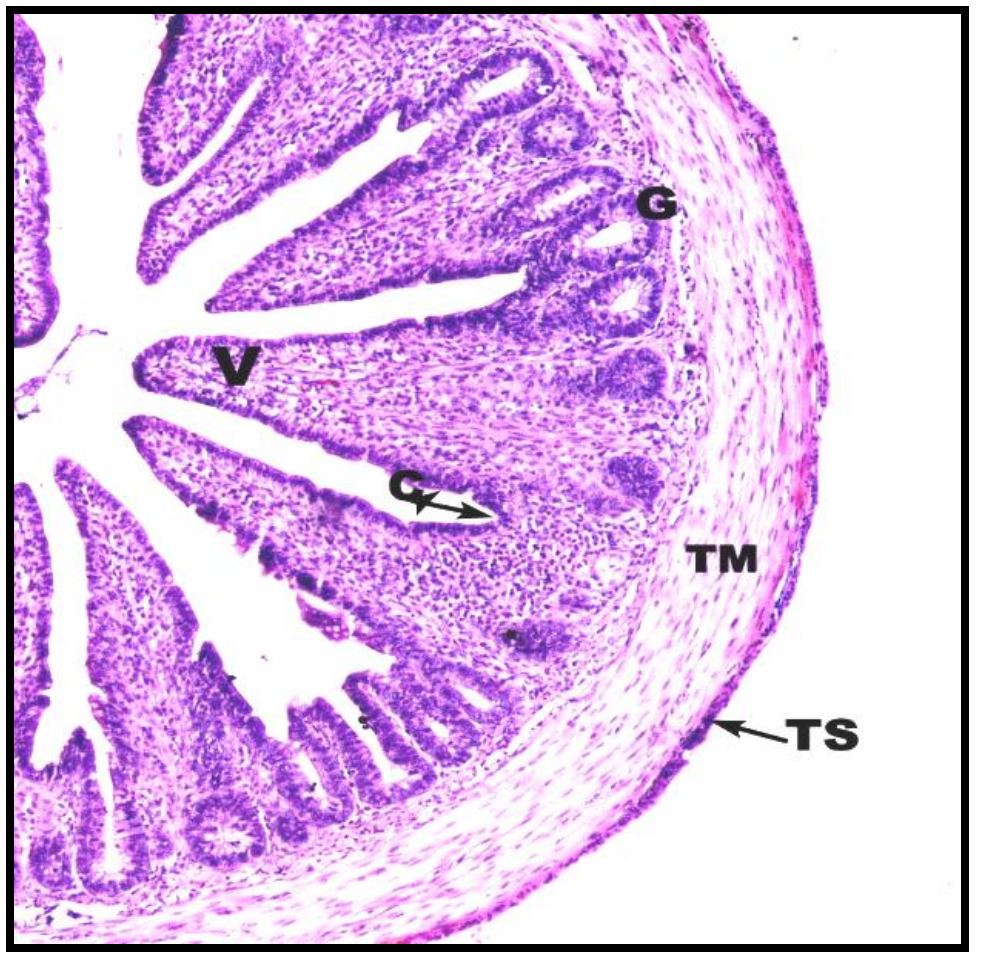

Fig.3 Photomicrograph showing network of reticular fibres (arrow) in lamina propria of proximal caecum in 28 day old caecum (Gomori's stain X400)

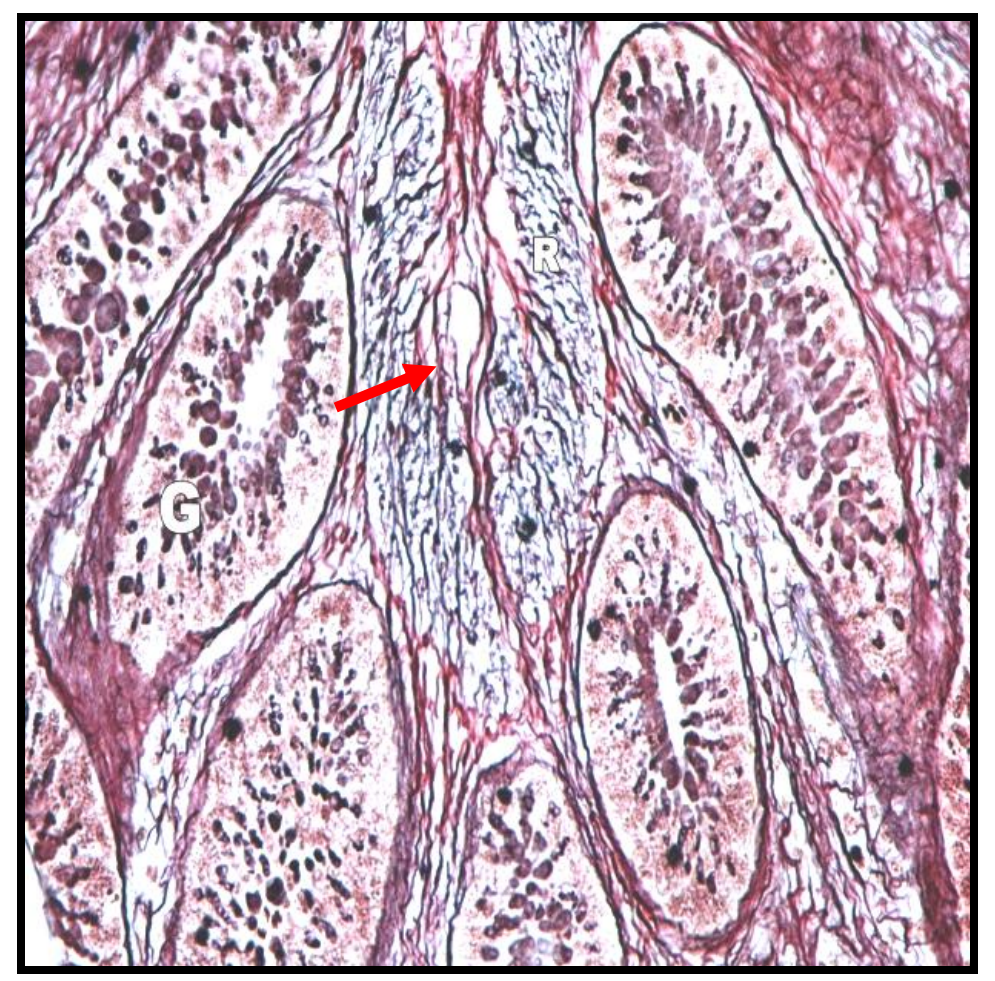


Fig.4 Photomicrograph showing blue colored collagen fibres (arrow) in core of villi, tunica submucosa and between tunica muscularis in distal portion of caecum in 112 day old bird

(Masson's trichrome X100)

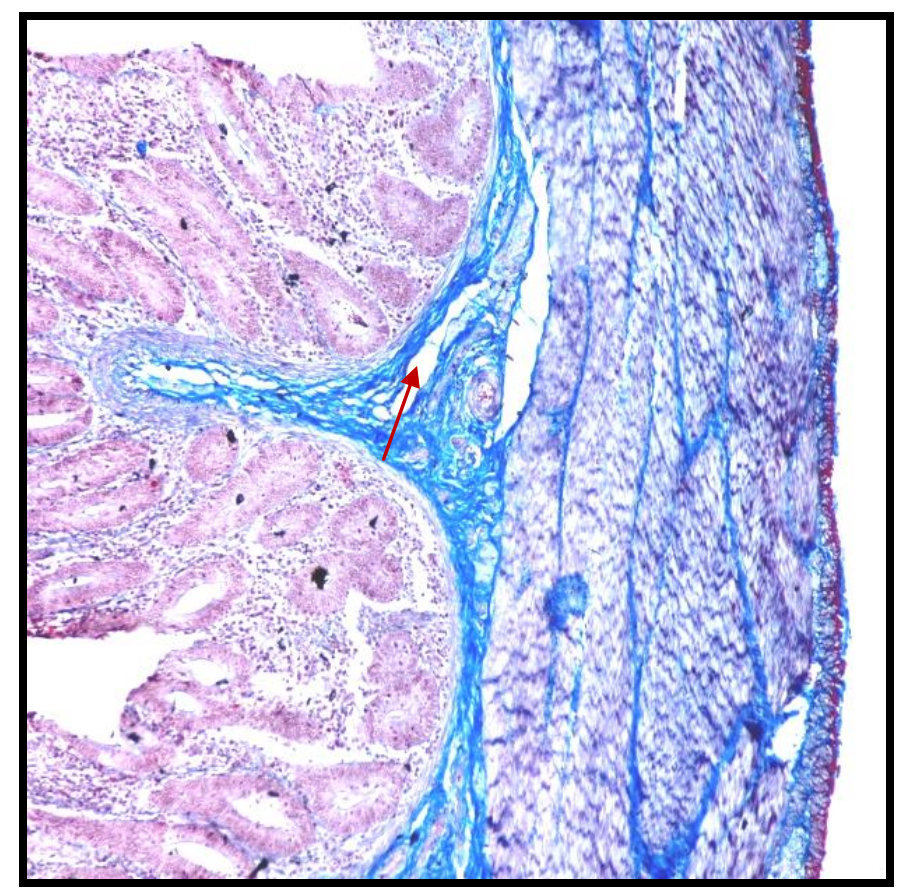

Fig.5 Photomicrograph showing Alcian blue activity (black arrow) in tip of villi and goblet cells and PAS activity in the lamina propria (white arrow) in proximal caecum of 112 days old bird (PAS and Alcian blue X1000)

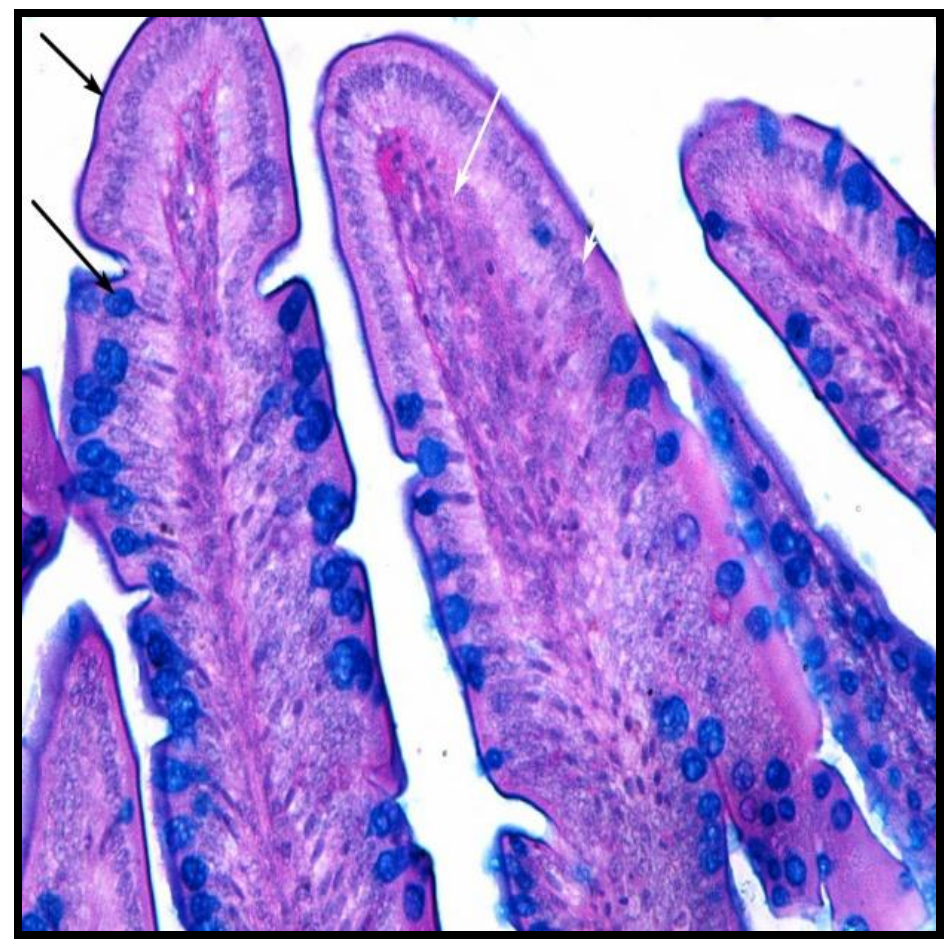


Fig.6 Photomicrograph showing black colored elastic fibres (arrow) in between muscle bundles of colorectum in 28 day old bird (Weigert's method X400)

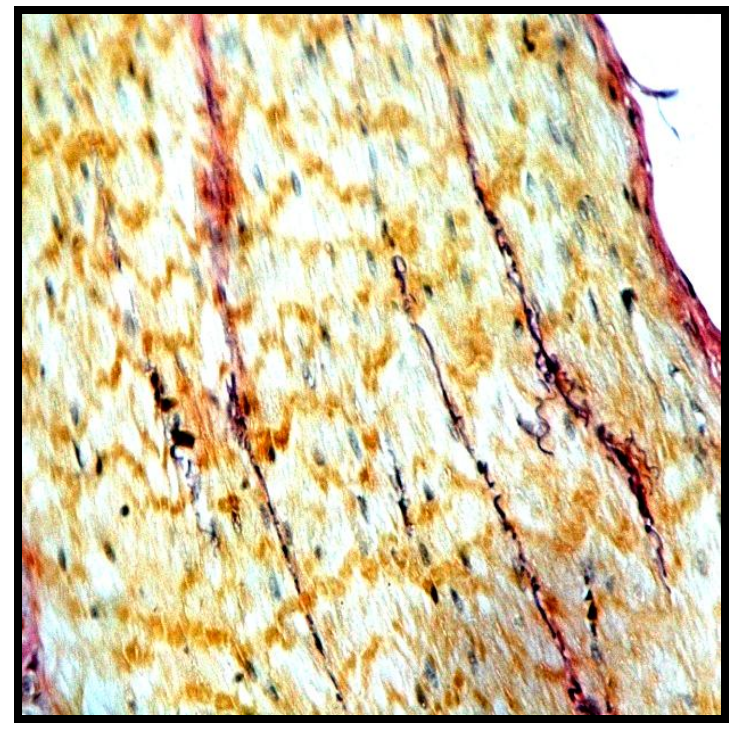

Fig.7 Photomicrograph of Argentaffin cell granules in intestinal gland of middle portion of caecum in 28 days old bird (Masson's Hamperl X1000)

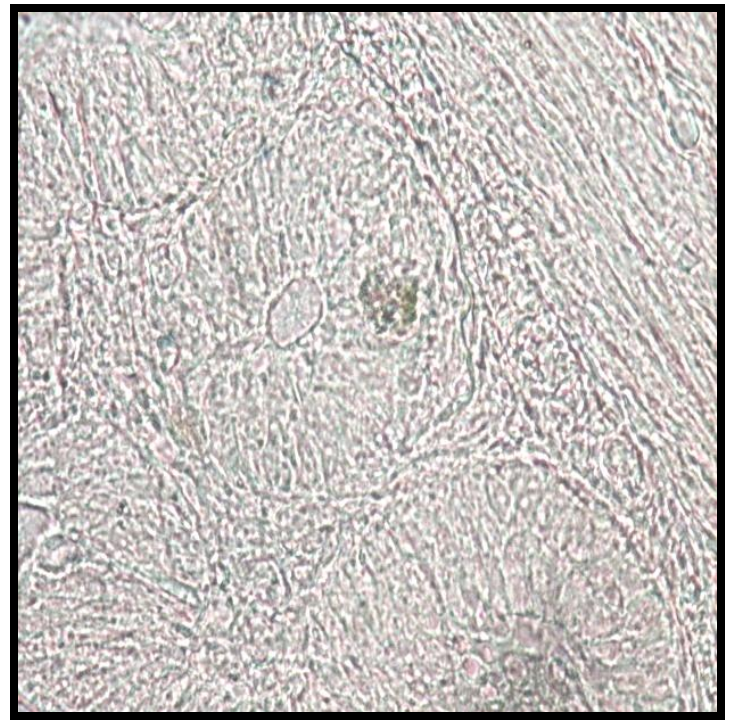

The thickness of tunica serosa increased from proximal to distal portions non-significantly in all age groups.

Samte (2008) recorded the mean thickness of the tunica mucosa, tunica submucosa and tunica muscularis of colon as $142.77,40.08$, $311.25 \mu \mathrm{m}$ at proximal, $154.88,45.65,378.95$ $\mu \mathrm{m}$ at the middle and $219.17,47.03,402.27$ $\mu \mathrm{m}$ at distal parts for day old, 208.38, 46.77, $532.97 \mu \mathrm{m}$ at proximal, 214.1, 49.8, 553.77 $\mu \mathrm{m}$ at middle and $278.88,52.72,632.97 \mu \mathrm{m}$ at distal parts for 7 -day old, 265.73, 131.42, $698.80 \mu \mathrm{m}$ at proximal, $287.68,68.89,723.80$ $\mu \mathrm{m}$ at middle and $342.25,81.61,879.32 \mu \mathrm{m}$ at distal part for 28-days old and 416.62, $119.53,1347.27 \mu \mathrm{m}$ at proximal, 421.92, 132.80, $1455.28 \mu \mathrm{m}$ at middle, 496.03, 
$163.03,1545 \mu \mathrm{m}$ at distal parts for 112-days Kadaknath fowl respectively. The height and breadth of the villi increased as the age advances. The mean villus length and breadth of the colorectum was $299.89 \pm 0.67$, $81.06 \pm 1.23 \mu \mathrm{m}$ at the proximal, $219.87 \pm 1.28$, $78.91 \pm 1.27 \mu \mathrm{m}$ at middle, 173.24 \pm 0.94 , $51.99 \pm 0.66 \mu \mathrm{m}$ at distal parts for day old; $365.25 \pm 0.89,127.09 \pm 1.26 \mu \mathrm{m}$ at proximal, $345.63 \pm 1.69,91.19 \pm 1.12 \mu \mathrm{m}$ at middle, $291.49 \pm 0.87,79.87 \pm 0.56 \mu \mathrm{m}$ at distal parts for 7- days; $965.93 \pm 0.35,143.51 \pm 1.32 \mu \mathrm{m}$ at proximal, $743.87 \pm 1.29,121.19 \pm 0.91 \mu \mathrm{m}$ at middle, $587.41 \pm 0.98,104.43 \pm 0.88 \mu \mathrm{m}$ at distal portion of 28 day old bird $1121.23 \pm 0.92$ and $120.21 \pm 1.94 \mu \mathrm{m}$ at proximal, $923.87 \pm 0.87$ and $221.18 \pm 2.08 \mu \mathrm{m}$ at middle, $691.49 \pm 1.23,137.19 \pm 1.22 \mu \mathrm{m}$ at distal parts for 112-days old Uttara fowl. Samte (2008) recorded mean villus length and breadth of the colon in Kadaknath fowl which was 293.89, 91.06 $\mu \mathrm{m}$ at the proximal, 211.08, $77.86 \mu \mathrm{m}$ at middle, $177.04,55.97 \mu \mathrm{m}$ at distal parts for day old; $375.25,117.09 \mu \mathrm{m}$ at proximal, 352.62, $98.17 \mu \mathrm{m}$ at middle, $298.47,77.59 \mu \mathrm{m}$ at distal parts for 7- days ; 976.88, $148.85 \mu \mathrm{m}$ at proximal, 752.62, $128.17 \mu \mathrm{m}$ at middle, 598.47, 208.17 $\mu \mathrm{m}$ at middle, $698.47,147.11 \mu \mathrm{m}$ at distal parts. The epithelial cell height and nucleus size was also recorded. Non-significant increase in both epithelial cell height and nucleus size was observed with advancing age. Mean epithelial cell height of caecum and colorectum was $17.88 \pm 0.23$ and $20.34 \pm 0.32$ $\mu \mathrm{m}$ for day old, $19.74 \pm 0.27$ and $21.13 \pm 0.24$ $\mu \mathrm{m}$ for 7 days old, $21.34 \pm 0.26$ and $22.72 \pm 0.29 \mu \mathrm{m}$ for 28 days old fowl, $23.68 \pm 0.38$ and $24.64 \pm 0.36 \mu \mathrm{m}$ for 112 days old Uttara fowl, respectively. Mean nucleus size of caecum and colorectum was $3.75 \pm 0.92$ and $3.71 \pm 0.18 \mu \mathrm{m}$ for day old, $4.25 \pm 1.23$ and $4.79 \pm 0.29 \mu \mathrm{m}$ for 7 days old bird, $5.08 \pm 0.79$ and $4.88 \pm 0.31 \mu \mathrm{m}$ for 28 days old and $6.5 \pm 1.43$ and $5.8 \pm 0.44 \mu \mathrm{m}$ for 112 days old Uttara fowl, respectively.

\section{Histochemical studies}

In caecum the lamina propria revealed strong reaction for reticular fibres in112 days old birds and black coloured fibres can be seen in the core of villi. In 28 days old birds moderate reaction was observed. In day old and 7 day old birds there was very weak reaction. Like caecum strong reaction for reticular fibres was observed in 112 days old uttara fowl's colorectum too. In 28 days old birds a moderate reaction was observed in colorectum. Day old and 7 day old birds imparted weak reaction with sparse reticular fibres (Fig. 3).

The Masson's Trichrome stain showed a very bright reaction for collagen fibers in the tunica serosa layers in caecum and colorectum of 112 days old birds. The intensity of stain decreased in younger birds. The staining reaction was also observed in the lamina propria, in crypts of Lieberkuhn, around intestinal glands, in core of villi and also between the muscle layers of tunica muscularis of all three segments of caecum i.e. proximal, middle and distal. Like caecum, colorectum also showed a strong reaction for collagen fibres. Fibers were abundant in 112 days old birds and decreased with decreasing age groups in studied age groups (Fig. 4). Similar observation was reported by Dellman and Eurell (1998) who observed the distribution of collagen fibre in the intestine of chicken and reported that collagen fibres were present in the core of the villi, around the intestinal glands, in the tunica submucosa, in the tunica serosa and the tissue separating the muscle bundles. Verma et al., (1999) reported that the collagen fibres of the intestinal walls predominated over the elastic and reticular fibres. They observed that the histochemical staining reactions revealed high colour intensity of collagen in small intestine than in the large intestine and concluded that the collagen concentration was more in the 
sub epithelium, core of the villi, around the intestinal glands, serosa and tissues separating the muscle bundles. These findings correspond with the present studies.

PAS and Alcian blue activity was demonstrated in the villus epithelium and the crypts of Lieberkuhn in both caeca and colorectum of Uttara fowl in all four different age groups for acid and neutral mucins. Villus epithelium, goblet cells and crypts of Lieberkuhn have acid and strongly sulphated mucopolysccharide secretions thus show reaction with alcian blue while neutral mucins are present in lamina propria showing reaction with Periodic Acid Schiff. Strong reaction was seen in 28 days and 112 days age group while moderate and weak reaction was observed in a day 7 and day old age group respectively in caeca. The epithelium lining at villi and crypts of Lieberkuhn of the colorectum showed more intense reaction for Alcian blue in 112 days old birds. The reaction was moderate in 28 days age group and became weaker in colorectum of 7 days old Uttara fowl (Fig. 5) while Aitkin (1958) found strong activity in 28 days old and moderate activity in 112 days old and weak activity in day old and 7 days old chicken and Ushakumary et al., (1994) in colon of quail. The crypts of Lieberkuhn of both caeca and colon show more intense reaction for Alcian blue in adult bird which indicates greater accumulation of acid mucopolysaccharides. A similar observation was observed by Ushakumary et al., (1994) in colon of quail.

The elastic fibres were very less frequent in day old, day 7 and 28 days old bird's caecum. The elastic fibres were present in lamina propria of ceacum in 112 days old bird. The elastic fibres were also observed in between muscle bundles of 112 days old bird. Weigert's elastic stain gave a positive reaction for elastic fibres around the major blood vessels in tunica serosa layers in all different age groups in caecum. Colorectum also showed same reaction for Weigert's stain as that of caecum. Sparse elastic fibres were present in lamina propria, between muscle bundles and around blood vessels in tunica serosa and tunica submucosa. The elastic fibres were found to be present in 112 days old bird in lamina propria and tunica muscularis in caecum as well as colorectum. In other studied age groups viz. day old, 7 and 28 elastic fibres were present only around blood vessels in both caecum as well as colorectum (Fig. 6).

Argentaffin cells in less numbers were dispersed in the villous and more in the gland epithelium in both caecum as well as colorectum. Maximum number of Argentaffin cells was found in 112 days old bird in both caecum and colorectum. The distribution of argentaffin cells and argyrophil cells were found to be less frequent in day old but their presence was noticed. The chromaffin cell granules were also less frequent and only a weak reaction activity was observed in the 28 day old Uttara fowl (Fig. 7). Schofield (1953) reported in the chick that argentaffin cells occasionally occur in group of 2-3 cells and are not invariably isolated from one another as in man, mouse and guinea pig. Aitkin (1958) stated that argentaffin cells were found at all levels of intestine including caecum and colon. The number of these cells in older birds was more numerous in the colon than in the small intestine other than in the area immediately following the transitional zone. There does not appear to be any connection between the argentaffin cells and the intestinal goblet cells in the chick. In chick intestine argentaffin cells are more in short proximal portion of duodenum and then declines throughout the length except a small rise in the colon.

The present age related histological, histomorphometrical and histochemical 
features of large intestine of Uttara fowl would immensely help in developing a baseline data for further studies in this field.

\section{Acknowledgement}

The authors are very much grateful to the Dean, CVASc., GBPUAT, Pantnagar and InCharge, Electron Microscopy Lab, GBPUAT, Pantnagar for providing necessary facilities in carrying out the research work in time. The authors are thankful to the Indian Council of Agricultural Research, New Delhi (ICARJRF) for providing the financial assistance.

\section{References}

Aitkin, R.N.C. 1958. A histochemical study of the stomach and intestine of the chicken. J. Anat. 92: 453-466.

Argenzio, R. A. 1980. Pathophysiology of diarrhoea. Veterinary Gastroenterology. Lea and Febiger publication Ltd., Philadelphia, USA. Pp. 172-198.

Bancroft, J.D., Layton, C. and Suvarna, S.K. 2013. Bancroft's theory and practice of histological techniques.

Bayer, R. C., Rittenburg, J. H., Bird, F. H., Chawan, C. B., and Allen, M. 1981. Influence of short term fasting on chicken alimentary canal mucosa. Poultry Science. 60: 1293-1302.

Braun, E. J., and Duke, G. E. 1989. Function of the avian cecum. J. Exp. Zool. Suppl. (USA). Pp. 16-22.

Calhoun, M. L. 1954. Microscopic anatomy of the digestive system of chicken. Ames, Iowa: Iowa State College Press. Pp:1-108.

Culling, C. F. A. 1969. In "Handbook of Histopatological technique (including museum technique)." 2: 228 - 238.

Dellman and Eurell, J. 1998. Textbook of veterinary histology. 5th Edition, Williams \& Wilkins, a waverly company, Baltimore, Philadelphia, London.

Fenna, L. and Boag, D.A. 1974. Filling and emptying of galliform caecum. Canadian Journal of Zoology 52: 537540.

Ferrer, R., Jana, M. P. and Durfort, M. M. 2008. Morphological study of the cecal epithelium of chicken. Brit. Poultry Sci. 32 (4):679-691.

Getty, R. 1975. Sisson and Grossman's the Anatomy of the Domestic Animals, 5th Edition. vol. 2. WB Saunders, Philadelphia, PA.

Giemsa, G. 1902. The azure dyes: Their purification and physiochemical properties. Zentralblatt fiir Bakteriologie Parasitenkunde infectienskrankherten and Hygiene. 31: 429.

Hamedi, H., Abdel-Wahab El-Ghareeb, Zaher, M., AbuAmod, F. 2013. Anatomical, Histological, Histo chemical adaptations of the avian elementary canal to their food habbits. IJSER. 4(10).

Kaur, N. 2007. Studies on morphological, haemato-biochemical and production traits in local hill fowl of Pithoragarh region. Ph.D. Thesis. G.B.P.U.A\&T, Pantnagar.

Kaur, N., Kumar, S., Singh, B., Pandey, A.K. and Somvanshi, S.P.S. 2010. Morphological characterization of feathered shank local hill fowl of Central Himalayan Region of India. Indian J. Anim. Sci. 80(9): 934-936.

Luna. L.G. 1972. Manual of Histological Staining Methods of the Armed Forces Institute of Pathology. The Blakiston Division, McGraw Hill Book Co. N.Y. Pp. 162, 163 and 164.

Majeed, M. F., F.S. Al- Asadi, F. S., Al. Nassir, A. N., Rahi, E. H. 2009. The morphological and histological study of 
the caecum in broiler chicken. Bas J Vet Res. 8:19-25.

Marshall, A.J. 1960. Biology and comparative physiology of birds. Vol. I. Academic Press, New York and London.

McManus, J.F.A. 1946. Histological demonstration of mucin after periodic acid. Nature. 158: 202.

McNab, J. M. 1973. The avian caeca: a review. Worlds Poult Sci J. 29:251-263.

Nasrin, M., Siddiqi, M. N. H., Masum, M. A. and Wares, M. A. 2012. Gross and histological studies of digestive tract of broiler chicken during post natal growth and development. J. Bangladesh Agril. Univ. 10(1): 69-77.

Nickel, R., Schummer, A. and Seiferle, E. 1977. Anatomy of the domestic birds. Verlag Paul Parey.

Samte, L. 2008. Gross morphometric, Light and electron microscopic studies on the large intestine of Kadaknath fowl. Master's dissertation G.B.P.U.A. \& T. Pantnagar.

Schofield, G. 1953. The argentaffin and mucous cells of the small and large intestine of the mouse. Acta. Anat. 18: 256-272.

Singh, I. 1964. On argyrophile and argentaffin reactions in individual granules of enterochromaffin cells of the human gastro-intestinal tract. J. Anat., Lond. Pp 497-500.

Sisson, S. and Grossman, J. D. 1953. The Anatomy of the Domestic Animals. Philadelphia: WB Saunders Company pp. 940-941.
Sivagnanam, S., Ramesh, G., Basha, S. H and Ushakumary 2004. Histological studies of liver in Guinea Fowl. Indian J. Vet. Anat. 16:21-25

Son, J. H., Karasawa, Y., and Nahm, K. H. 2000. Effect of caecectomy on growth, moisture in excreta, gastrointestinal passage time and uric acid excretion in growing chicks. Brit. Poultry Sci. 41(1): 72-74.

Turk, D. E. 1982. The anatomy of the avian digestive tract as related to feed utilization. Poultry Science. 61: 12251244.

Ushakumary, S., Geetha Ramesh and Vijayaraghavan, C. 2002. Lymphoid aggregation in caecum and colon of Japanese Quail. Indian Journal of Veterinary Anatomy. 14:16-21.

Vaish, M.K., Parmer, M.L., Taluja, J.S. and Vaish Rakhi. 2006. Histological observations on the large intestine of posthatch Kadaknath Fowl. In "Souvenir and Abstracts" xx Annual Convention of Indian Association of Veterinary Anatomistsn and National Symposium held on 27-29 Jan., 2006 at Jabalpur. Pp.54.

Venkatesan, S., Ramesh, G. and Vijayaragavan, C. 2005. Age related changes in histomorphology of the spleen of the Japanese Quail. IJVA.17:19-23.

Verma, D., Malik, M.R., Shrivastava, A. M. and Parmar, M. L. 1999. Histogenesis of intestinal villi in fowl (Gallus domesticus). Indian J. Anim. Sci. 69(11): 902-904.

\section{How to cite this article:}

Pandit, K., B.S. Dhote, D. Mahanta, S. Sathapathy, S. Tamilselvan, M. Mrigesh and Mishra, S. 2018. Histological, Histomorphometrical and Histochemical Studies on the Large Intestine of Uttara Fowl. Int.J.Curr.Microbiol.App.Sci. 7(03): 1477-1491.

doi: https://doi.org/10.20546/ijcmas.2018.703.176 